\title{
Agricultural Short Message Services as Information for Farmer Empowerment
}

\author{
Djuara Lubis, Asri Sulistiawati*
}

Department Communication and Community Development Science, IPB University, Bogor 16680, Indonesia *)E-mail of correspondence: asrisulistya@apps.ipb.ac.id

Submit: 9 January 2021 | Accept: 9 April 2021 | Published: 23 April 2021

\begin{abstract}
Layanan Informasi Desa/Rural Information Service (LISA) is an information service for farmers based on SMS. It is used to disseminate agricultural information and provide a space for agricultural tips, ask questions and have a discussion. This study was conducted to determine the response and the perceived benefits of these services for farmer households. The study was conducted in Karawang, where LISA was launched. The results showed that the frequency of LISA'S use varied greatly from once per week to 30 times per week, but no farmer household used Android-based applications. The frequency of use of these services is significantly related to satisfaction level and is associated with the level of knowledge of farmer households. On the other hand, the frequency of use of LISA is unrelated to the characteristics of farmer households, which include age, education, sex, land ownership, as well as participation in farmer groups, and cosmopolitanism. A higher level of knowledge is also related to the suitability of the tips given by LISA and the degree of satisfaction with the LISA.
\end{abstract}

Key words: accessibility, digital, exposure, ICT title of the work, journal citation and DOI. 


\section{INTRODUCTION}

The use of Information and Communication Technology (ICT) is important in every aspect of life, especially on building a nation, not to mention agricultural development. Overseas Development Institute (2008) hinted that ICT must be used broadly to develop rural areas, including to alleviate poverty. Along with the development of ICT in Indonesia, the use of ICT which originally focused on a trade sector now increasingly develop into a technology that can be used to broaden services and to improve knowledge. Amin, (2018) stated that ICT had been broadly used in Indonesia; however, it was mostly used for entertainment and social media. While Daum (2018) research showed that the application of ICT gave an amazing opportunity for the food security and sustainability. This finding was reinforced by Kante et al., (2019) research results which uncovered that the use of ICT significantly influenced the adoption of agricultural information. The success of using ICT for the agricultural development with its requirements was also reported by FAO (2010) in Egypt and by Megan et al., (2015) in Afghanistan.

The presence of ICT directly shifted the old ways in the development of agricultural sector. As an example, in the service of giving information which originally mostly uses interpersonal communication between a farmer and an extension worker, or among farmers in a farmers group, now this activity can be done without having to meet by using various media such as SMS, internet media, such as social media. According to the literature study done by Amin (2018), there was a big effort to utilize ICT for the rural areas development, especially in the agricultural and fishery sector. In fact, it was a long time ago that Chapman \& Slaymaker (2012) mentioned the hug potential of ICT for rural areas development. They stated that information was an important key on rural areas development, and ICT was an important tool for searching, saving, and distributing information. As for the context in Indonesia, the mostly used ICT tools by farmers and fishermen are handphones (Center for Research and Post and Informatics Development, 2015).

Meanwhile, Rendra \& Wulandari (2017) also stated that the service for agricultural sector in Indonesia must be improved. So far the development of ICT for agriculture has been underdeveloped compared to other sectors. They believed that ICT could be developed to get the farmers closer to the other stakeholders. In turn, the farmers' welfare will be improved by using the capacity of ICT.

On the other side, All Answers Ltd (2018) elaborated that specifically rural areas needed various intervention to improve the welfare of its people. ICT can facilitate this intervention. For the intervention to be more efficient, a strong coordination is needed between these various sectors. This is in line with what has been put forward by Daum (2018), there were some challenges such as providing supporting infrastructure and making sure the equal access, data ownership, and privacy.

Aside from that, there are also parties, both government institution and civilian institutions that provide this information services for the development. It is interesting to research on the effectivity of this ICT services for spreading the information of the development, especially the development of agricultural and rural areas. In addition to its effectivity to spread information, it is also necessary to know how the society can use that information to improve their welfare.

One of the examples of using ICT for the agricultural development was done by Mercy Corps Indonesia, an NGO who introduced the use of ICT for farmers empowerment. This institution, through Agri-Fin Mobile, provided technology and financial information services for the farmers of paddies, corns, chilies, and potatoes in various areas. This service is known as Rural Information Services that uses cellular telephone equipment in the form of Short Message Services (SMS).

With reference to the World Bank (2011), on designing ICT intervention in the agricultural sector, some things need to be emphasized, among others, the farmer's access to ICT is not only physical proximity, infrastructure accessibility, ICT tools and services, but also the affordability, usability, and usability model that is in line with the local condition of the physique, environment, and culture. Even though it is realized that ICT has an important role on supporting sustainable agricultural development, until now the farmers of the world, especially in Indonesia, are still not taken into account in the ICT business and policy environment (Lubis, 2010).

Furthermore, there are many researches that prove the benefits of ICT in the agricultural world. One of them was by Park (2017), he stated that the general benefit of information technology was to overcome distance barriers through online services, to improve the social modal level among community members, and to achieve economic benefit with the possibility of participating in the digital economy. Previously, 
World Bank (2011) identified four fields where the application of cellular phones can promote the development of agricultural and rural areas including better access to the information of markets, diseases, climates, and extension services.

Furthermore, Baumüller (2013) added that the services presented in mobile service (m-service) could give information to farmers both according to demand or by sending update through SMS or audio recording. This m-service also functions to facilitate farmer-to-farmer or farmer-to-buyer relationship, such as sharing their experience on agricultural practice and market information on price, supply, and demand.

On the other side, the use of ICT, especially phone cellular, in agricultural sector cannot be separated from the influence of its own user characteristics. In other words, the characteristics of the user - in this case the farmers - are related to the utilization level of cellular phone in accessing agricultural information. This has been stated by Adegbidi et al., (2012) on his writing with respect to the determining factor of cellular phone users by farmers, some of which include education, experience, and land tenure area. Furthermore, other researchers such as Ono \& Zavodny (2007); Stiakakis et al. (2010); Haight et al. (2014); and Robinson et al. (2015) stated that demographic and social characteristics influence the level of ICT use; furthermore, the different characteristics can cause digital inequalities.

Based on the things discussed above, this research aims to identify to what extent the use of technology information (especially SMS service for farmers) is conducted by farmers in Karawang, West Java. Besides, this research also examines further the implication of the use of the SMS service towards the improvement of the farmers' knowledge.

\section{RESEARCH METHOD}

The research was conducted from July until October 2017. It was held in five districts, namely Pangkalan, East Karawang, Jatisari, Pedes, and Rawamerta in Karawang Regency, West Java Province. The site selection was carried out purposively with 200 farmers who used LISA services as samples. The list of farmers who used LISA was obtained from the Mercy Corps Indonesia.

This research was designed using a quantitative approach with survey methods. Quantitative data collection was carried out by a structured interview using instruments, such as questionnaire. Qualitative data collection was carried out through a profound interview and a group interview. The profound interview was conducted by the staff of Mercy Corps Indonesia (at their headquarters in Karawang), together with agricultural field counselors in areas that have LISA services.

\section{RESULTS AND DISCUSSION}

\section{Description of Agricultural SMS Services}

Rural Areas Information Service is an information service done by Agri-Fin Mobile. This program was built by Mercy Corps Indonesia and PT 8Villages Indonesia that provide integrated services to lowincome farmers. These services were built to help farmers with all their limitations to access information for their farming business, such as weather, consumer needs, selling price, and costs that need to be incurred to do farming.

In the beginning of this program, partnership between the local government (especially Department of Agriculture and Extension Coordination Agency), Mercy Corps Indonesia and 8Villages was done for the training. This training was attended by all of the farmer's agricultural land extension workers and farmer figures, especially agricultural group leaders within the service area. This training aimed to introduce LISA services and how farmers could get the access to it, and how the field agricultural extension workers and agricultural group leaders could help farmers to access this service.

Rural Areas Information Services used SMS and were introduced in December 2021 in Karawang Regency. The range of LISA covers four regencies in the province of West Java, namely Karawang Regency, Purwakarta Regency, Subang Regency, and Bogor Regency.

Information services through SMS was chosen because this service was the simplest and relatively cheap. This service could reach farmers with simple handphones, and the services was cheap because it did not need an internet connection. Indeed, because of its simplicity, messages sent through SMS was short and could not load images. Because of that, these services could not load complex information. 
Agricultural SMS Services include services such as agricultural tips and Q\&A as well as family financial literacy services. The materials for guidance are based on a thematic operator that refers to the government program, originating from developed trends in the society, or themes which are of concerns in interactive Q\&A service users. The community can use these services on Agri-Fin Mobile by first signing up through their cellular phone by sending SMS in accordance with the instructions given and sent to the operator number 2000. After signing up as a user, then the user can use some services provided, such as agricultural tips and interactive Q\&A service with the agricultural experts. At the beginning of the service from December 2012 to April 2015, agricultural tips were given to its users every day. Because of the limitation in sending short messages, LISA operator shared one theme of agricultural tips by sending SMS two times. Next, as of May 2015, agricultural tips services were carried out twice a week.

Farmers who want to get the LISA services must sign up through cellular phone by typing "FOLLOW (space) LISA (space) PHONE NUMBER registered" and send it to 2000. After signing up as an LISA user, then in that phone number various information services will show up, such as agricultural tips and interactive Q\&A with the agricultural experts.

To arrange the messages that will be sent, Mercy Corps work together with an agricultural higher education. Experts from this institution will arrange the information and answer the questions asked by the LISA users.

To attract users, Mercy Corps Indonesia conducted a weekly quiz. With these quizzes, Mercy Corps would know the knowledge and memory of its users of the disseminated messages. Every week 10 winners were chosen and each winner would be given a Rp 10.000 pulse.

They attempted to answer every question that came through SMS. To improve its user's activeness, LISA sometimes gave Rp 5.000 pulse to each user who asked question.

\section{Characteristics of Farmer Users in Karawang}

Information and communication technology (ICT) users cannot be separated from the farmer's characteristics. Referring to Adegbidi et al., (2012) in their notes, the defining factors of cellular phone users by farmers include education, experience, and land tenure area. Furthermore, other researchers such as Ono \& Zavodny (2007), Stiakakis et al. (2010), Haight et al. (2014); Robinson et al. (2015) stated that the characteristics influenced the level of ICT use; moreover, those different characteristics could cause digital inequalities.

Table 1 Number and Percentage of Farmers According to Their Individual Characteristics

\begin{tabular}{llll}
\hline $\begin{array}{l}\text { Individual } \\
\text { Characteristics }\end{array}$ & Category & Number & Percentage \\
\hline \multirow{4}{*}{ Age (Year) } & Young $(<30)$ & 28 & $14 \%$ \\
& Adult (30-50) & 124 & $62 \%$ \\
& Old >50 & 48 & $24 \%$ \\
\hline & Primary School & & \\
Formal Education & Middle to High & 176 & $88 \%$ \\
& School & 17 & $8 \%$ \\
& College & 7 & $4 \%$ \\
Cultivated & Small $(\leq 4,000)$ & 94 & $47 \%$ \\
Areas (m $\left.{ }^{2}\right)$ & Moderate $(>4,000-\leq$ & & $41 \%$ \\
& Land & 81 & $13 \%$ \\
\hline \multirow{4}{*}{ Land } & Large $(>12,000)$ & 25 & $33 \%$ \\
Status & Labor & 66 & $9 \%$ \\
& Pawn & 17 & $29 \%$ \\
\hline
\end{tabular}




\begin{tabular}{|c|c|c|c|}
\hline $\begin{array}{l}\text { Individual } \\
\text { Characteristics }\end{array}$ & Category & Number & Percentage \\
\hline \multirow{3}{*}{$\begin{array}{lr}\text { Amount } & \text { of } \\
\text { Information } & \\
\text { Technology } & \text { Media } \\
\text { Owned } & \end{array}$} & Few $(\leq 1)$ & 86 & $43 \%$ \\
\hline & Moderate $(2-3)$ & 16 & $8 \%$ \\
\hline & Plentiful ( $\geq 4)$ & 98 & $49 \%$ \\
\hline
\end{tabular}

As for the farmer's characteristics which are measured in this research included age, formal education, land tenure status and level of communication media ownership. The following is the data of the number and percentage of farmers according to their individual characteristics.

The classification of age in this research is divided into 3 categories including young age which is below 30 years-old, adult with age span between 30 until 50 years-old and the old category aged older than 50 years-old. Referring to the data shown in the table above, it is seen that more than half of the farmers are classified into the adult category with age span over 30 years-old. Meanwhile, at least young farmers who were identified less than 15\% could strengthen the fact about there was a low interest in the young towards agriculture. This is in line with the agricultural census result in 2013 , stating that farmers $(<30$ years-old) were about $13 \%$.

According to the formal education taken, farmers in Karawang Regency in general were lowly educated. As much as 88 percent of farmers were only elementary school and some even did not finish elementary school. There was an interesting data, even though the percentage was only 4 percent, there were farmers in Karawang Regency who took college education. This shows that there are already college graduates who were interested in the agricultural sector. This is in line with the data presented by the Agency for Agricultural Extension and Human Resources Development (BPP SDMP) in 2016, saying that the percentage of agricultural workers (farmers) according to their education in Indonesia mostly was in the low category with 74 percent. As for the other 34 percent, it consists of those who were never educated (10 percent) and those who never finished elementary school (24 percent).

On the other side, even though Karawang Regency is known as one of the granary areas in Indonesia, the fact shows that only a few farmers own large lands ( $>1$ hectare) with the percentage of less than 15 percent. Almost half of the farmers are small-field farmers with land ownership area less than half of a hectare, with the percentage of 47 percent. This fact is in line with the data related to the land tenure status that 30 percent of the farmers are landless and they are farm workers.

The table above also shows the symptoms of imbalance in land ownership. There are 13 percent of farmers who own more than 1.2 hectares; there are even some cases where the farmers own up to 20 hectares of land, while the other 30 percent do not own land. This land ownership polarization symptom is a threat that causes difficulties in agricultural development.

Next, if it is seen from the number of communication media ownership, there are some interesting data which show disproportions among farmers. Half of the total number of farmers own not more than one medium (43 percent), as for the media commonly owned is television. On the other side, half of the other farmers own more than 4 media (49 percent) including television, radio, cellular phone, computer, and even laptop.

\section{The Use of SMS Service for Agriculture}

As reffered to FAO, (2010), it is important to use ICT for agricultural development and food availability. FAO sees that through ICT, (a) information can be accessed by all parties involved in the agricultural development, and (b) transaction fees can be reduced. It means that ICT can give various advantages to agricultural development, so that the country and the world must encourage to use ICT in agricultural sector. Furthermore, referring to what Jain et al., (2015) stated, agricultural information system must be developed according to mass communication technology, such as electronic media including ICT. Basically, information received by the LISA user farmers are the same for everyone. LISA spreads information at the same time and amount to everyone. However, some individual factors made farmers receive the amount of information, access frequency, and amount of information variety differently.

The level of farmer users for agricultural SMS service in this research was measured by three indicators, namely the amount of information sources, access frequency and amount of information variety. The amount of information sources shows how much agricultural information sources can be accessed in a 
month, while the information variety is measured by the variety of information related to the farming activities. As for the information frequency, it is measured according to how much agricultural information can be accessed from various information sources in a month. Therefore, the following are data on the level of farmers using agricultural SMS services.

In accordance with the number of information sources available in the rural information services, there are three information sources: price information, agricultural tips and Q\&A, and also family financial literacy service. The guidance materials are based on LISA thematic operator which refers to the government programs, and from the trends developing in society, or themes that attract users in the interactive Q\&A. The result of the research shows that almost all of the farmers have moderate amount of information, which comes from four to six information sources.

Table 2 Number and Percentage of Farmers According to the variable of Level of Agricultural SMS Service User in Karawang Regency in 2017

\begin{tabular}{lllll}
\hline Level of Use & & Category & Number & Percentage \\
\hline \multirow{2}{*}{ Amount of } & \multirow{2}{*}{ Information } & Little (1-3) & 0 & $0 \%$ \\
Sources & & Moderate (4-6) & 198 & $99 \%$ \\
& & A lot (7-9) & 2 & $1 \%$ \\
\hline \multirow{2}{*}{ Amount of } & \multirow{2}{*}{ Information } & Little (1-3) & 185 & $93 \%$ \\
Variety & & Moderate (4-6) & 15 & $8 \%$ \\
& & A lot (7-8) & 0 & $0 \%$ \\
\hline \multirow{2}{*}{ Information } & \multirow{2}{*}{ Arequency } & Little (1-10) & 88 & $44 \%$ \\
& & Moderate (4-6) & 46 & $23 \%$ \\
\hline
\end{tabular}

The small number of farmers who have information sources is in line with the next finding about the amount of information variety accessed where the data show that at the average users can only access one to three types of information. Therefore, it can be said that almost all of the farmers have not tried to access all of the information available in LISA agricultural SMS services. Furthermore, the type of information accessed frequently by farmers is usually about farming Q\&A, while the average farmers confess that they have never accessed family financial literacy services because some of them assume that that information is not necessary, and some others assume that the information is hard to understand.

From in-depth interviews, it was found that the variety and low level of the number of information sources, amount of information variety, and the frequency of information received are caused by the uneven ownership of handphones. In the research areas, it turned out that for many families handphones were not "personal belongings" but it was a family belonging.

It might happen that when LISA spread information related to agricultural technology, the handphone was taken by their child to school. Or there was information about household economy, but the phone was being carried by the father. As a result, the information could not be accessed by the target individual who was supposed to get the information.

These circumstances are getting harder because generally the "phone memories" are relatively small. If there is an incoming short message, the memory fills up fast. What can be often done was erasing the existing information. This caused the variety of information received by respondents. This shows that the symptoms of digital inequality among farmers in Karawang Regency. In this case, the uneven ownership of gadgets to access digital information.

Related to the types of information accessed by the farmers, these are the data on the types of farming information accessed by the farmers of Karawang Regency through LISA services.

Table 3 Number and Percentage of Respondents According to the types of Farming Information Obtained Through LISA Sources in Karawang, 2017

\begin{tabular}{lll}
\hline Types of Farming Information & Number & Percentage \\
\hline 1. Tillage & 92 & 46.00 \\
2. Irrigation & 48 & 24.00
\end{tabular}


The number of farmers who received farming information, especially the one related to rice cultivation technique, was still less than 50 percent. This phenomenon is quite interesting, because some of the farmers were not exposed to farming information, which was the main business of farmers, whereas LISA had been sending agricultural information. Indeed, information served by LISA was short and general, because of the SMS limitations, but there was no way a complicated and profound technology could be sent through SMS.

Information about land cultivation received by farmers was not immediately implemented in its farming. For example, LISA recommended farmers not to burn hays, but to let it rot in land. This treatment was important to fix the fertility of the land. In reality, most of the farmers did not do this recommendation. It means that they burned the hays. According to the farmers it was the easiest and quickest way, because they must quickly cultivate the land so that they could work in the next growing season. Waiting for the hay rotting process needed a long time, and it caused them to miss the growing season.

The information most received by farmers was related to pest and plant diseases (56.50 percent) and also fertilization and tillage (each 46.00 percent). The information rarely received from LISA was about irrigation, selection of seeds, planting, and post-harvest, while the rarest information received was about marketing.

In fact, very few farmers were exposed to marketing information. This shows that farmers were still the receivers of the price in farming, especially in rice farming. They did not have many choices in rice marketing. Merchants decided the farmer's product prices. Institutionally, indeed there was very little protection for farmers to market their agricultural products. Rice farmers often became the victims of rice commerce. During the harvest season, farmers sold their rice with low prices (because of the overflow of supply), and during famine season they bought rice with high prices. (many farmers did not have barn, so they could not store rice in large quantities for their needs in the next season).

On the other side, even though the data show a small number of farmers who owned sources and information variety were classified in the high category, the frequency of the farmers accessing the LISA services was quite good. This is shown from the data presented in Table 2, showing that 33 percent of the farmers confessed to frequently access LISA services with the average frequency about 21 to 30 times in a month. Farmers in this category confessed that at least once a day they used LISA services.

However, on the other side almost half of the other farmers confessed to rarely access LISA services with the frequency of less than 10 times in a month. This is caused by the average farmers in this category only owned one shared handphone in one family. Because of it, to use handphone they must take turns. Other than that, there were other limitations on accessing LISA services caused by the farmers' unskilled use of handphones, keeping in mind that 24 percent of the farmers in this research were classified in the older age category (more than 50 years old), and most of them were elementary school graduates. Because of it, on using handphones, especially on accessing LISA, farmers in this category still needed help from other members of their family.

Furthermore, the low frequency of farmers utilizing the Q\&A forum on LISA services among others is because farmers assume the writing in the cellular phones was too small so it is hard for them to read. Description through SMS was also considered not to be complete and clear. Farmers tended to be using the facility less and less because the answers received were not obtained directly. There were also farmers who presumed the answers given were too long and hard to read.

Based on the description above, it can be said that the level of accessibility of farmers towards LISA services is not yet in the high category. This is caused by a number of reasons, one of which is farmers are still facing various obstacles in utilizing LISA application. One of the reasons expressed by the farmers was the slow response on getting a reply. There were other farmers who expressed that the answer received was not detailed and eventually the farmers tended to ask directly to other farmers. Other 
obstacles regarding the communication were the language that was difficult to understand so they did not understand what was delivered.

This becomes a clue that there is a digital inequality in another form. The farmers' low level of formal education caused the low ability to use LISA services. Even though the information is available, and it can be accessed evenly, the ability of farmers to read and understand the message content becomes varied. Once again, this shows a digital inequality phenomenon among farmers who use LISA services.

This finding is in line with the finding of Sari et al. (2018) which mentioned the importance of ICT infrastructure improvements so that there were more people who could access ICT. This physical infrastructure improvements must also be accompanied by the effort of the farmers to access the information, such as charging lower rate so that there are more farmers who can gain access to the information

\section{Level of Agricultural SMS Use and Level of Farmers' Knowledge}

With refer to the finding by Meera et al., (2004) in their research regarding the use ICT in three projects in India, it shows that the respondent's age is negatively correlated with the frequent use of internet services in the three ICT projects. In line with this, Aldosari et al., (2019) expressed that age influences significantly the information access rate originating from electronic media like television, radio, and internet. Land ownership, on the other hand, does not correlate at all with the frequent use of ICT services. In other words, all farmers can access media, no matter how big the land they own. In the meantime, the research finding by Senthilkumar et al., (2013) showed that land ownership and farmer's knowledge are significantly correlated with the rate of ICT use like Village Information Centre (VIC).

Therefore, the rate of farmer's use of SMS for agriculture is closely related to its influencing factors, both internal and external. The internal factors mentioned in this research are related to the farmer's characteristics by referring to a number of previous researches (Meera et al., 2004); (Ono \& Zavodny, 2007); (Stiakakis et al., 2010); (Senthilkumar et al., 2013); (Haight et al., 2014). The following table presents data about the correlation test between the farmer's characteristic variable and the one used in the information accessibility rate.

With reference to the data presented in Table 4, it can be seen that the farmer's characteristic variables that are related to the number of information sources that can be accessed by farmers are formal education and farming land area. The type of relation resulting from the data is positively correlated and very significantly real $(\alpha)$, in that they are respectively 0.000 and 0.007 . Therefore, the higher the farmer's formal education, the more information the farmer can access. This shows that farmers of higher education can explore various sources of information in LISA.

Table 4 Correlation Coefficient between individual characteristic variable and that of farmer's SMS use in Karawang Regency in 2017

\begin{tabular}{lcccccc}
\hline \multirow{2}{*}{ Farmer's characteristics } & \multicolumn{6}{c}{ Rate of cellular phone use } \\
\cline { 2 - 7 } & $\begin{array}{c}\text { Source of } \\
\text { information }\end{array}$ & $\begin{array}{c}\text { A variety of } \\
\text { information }\end{array}$ & $\begin{array}{c}\text { Frequency of } \\
\text { information }\end{array}$ \\
\hline Age & $\mathbf{r}$ & Sig & $\mathbf{r}$ & Sig & r & Sig \\
\hline Formal education & -0.17 & 0.816 & 0.016 & 0.826 & $-0.206^{* *}$ & 0.003 \\
\hline Area of farming land & $0.414^{* *}$ & 0.000 & $0.240^{* *}$ & 0.001 & $0.210^{* *}$ & 0.003 \\
\hline Status of land ownership & $0.189^{* *}$ & 0.007 & 0.087 & 0.219 & $0.503^{* *}$ & 0.000 \\
\hline IT media ownership & 0.118 & 0.095 & $0.196^{* *}$ & 0.005 & $0.179^{*}$ & 0.011 \\
\hline
\end{tabular}

*there is a significant correlation at $\alpha 0,05 ; * *$ there is a real correlation at $\alpha 0,01$

In terms of area of land managed, the correlation test shows that the larger the land area the farmers managed, the more information the farmers could access. However, when it is seen from the variety of information, there are three variables that are related with the number of information variety that can be 
accessed by farmers. These include level of formal education, status of land ownership, and ownership of information technology media.

On the other hand, communication frequency is the only variable in the accessibility level that is correlated with all variables in the farmers' characteristics. The interesting data that result from the correlation test between age characteristic and information frequency shows that it correlated negatively and significantly at real level $(\alpha) 0.003$. The negative correlation shows that the older the farmers, the less frequent farmers get access to agricultural SMS services. This strengthens the thesis that older generation (digital migrant) have difficulty to use digital information. This older generation felt awkward to use digital media, so the frequency they use media tend to be lower compared to the young generation (digital generation).

The correlation between area of land ownership and level of farmers to use SMS services previously indicated by Adegbidi et al. (2012) who showed that the use of cellular phones in farming activities is influenced positively by the land they own and grow. The results of this research showed the same. The land area farmers own is correlated positively with the level of agricultural SMS use. The indicators of the level of use mentioned here are among others number of information sources and frequency of information. In other words, the more the land area owned by farmers, the more sources of information the farmers can access in line with the more often they access the information.

This is also related to the 'courage and opportunity' of the farmers to use technology. Farmers who own a large farming area has more chance to use technology that varies in their large farming area. Farmers who own small area of land do not often use technology in their limited farming area. This limitation is related to the risk of farming and cost for innovation. Large farming area farmers dare to take risk to try innovation because they have enough asset. It is unlike small-farming area farmers who have little asset. So is the cost for innovation; big farmers have enough fund to pay for the innovation, whereas small farmers do not own it.

There is an interesting thing in using information obtained from LISA services. Although farmers do not practice it directly, this information is actually is used by field counselors as a topic for discussion with farmers. The extension workers discuss the information from the SMS with farmers. Sometimes the initiative comes from farmers (meaning farmers ask further the information they get from LISA), and sometimes the initiative comes from the extension workers (meaning the extension workers make use of the information from LISA as a topic for discussion with farmers). This is in line with the research by Anastasios et al., (2010) who said that in agricultural extension, there was a big challenge to combine information technology with conventional communication mode (face-to-face and group discussion). Therefore, although LISA information is indirectly practiced by farmers, this information is very useful to connect farmers and the extension workers. Furthermore, the rate of SMS services is an important factor to determine the change in farmers' knowledge about a number of information they obtain from LISA services. Data on the correlation test about both variables can be seen in the following table.

Table 5 Coefficient Value of the Correlation between Information Accessibility and the Knowledge Level of Farmers in Karawang Regency, 2017

\begin{tabular}{lcc}
\hline \multirow{2}{*}{$\begin{array}{l}\text { Information } \\
\text { Accessibility }\end{array}$} & $\mathbf{R}$ & Level of Knowledge \\
\cline { 2 - 3 } & $0.170^{*}$ & Sig \\
\hline Source of Information & 0.155 & 0.016 \\
Variety of Information & $0.535^{* *}$ & 0.028 \\
Frequency of Information & 0.000 \\
\hline
\end{tabular}

*there is a real relationship in $\alpha 0.05, * *$ there is a real relationship in $\alpha 0.01$

Referring to the data shown on Table 5, it is known that the variables contributing to the knowledge of the farmers are the source of information and the frequency of the information. In other words, the more information the farmers access, the higher the farmers get knowledge. Meanwhile, the variety of the information is not related to the level of the farmer's knowledge, in connection with the fact that almost all of the farmers are not yet trying to access the information available in the LISA services. Furthermore, the types of information that are usually accessed by the farmers are Q\&A services on farming, while the 
average farmers confess they never access family financial literacy services because some of them thought that the information is not necessary, and some others thought that that information is not easy to understand. In other words, the results of this research can give an input especially for the service providers that what the farmers need is actually to access the information and not how many varieties of information are available. The agricultural SMS service providers are expected to focus on the topics that are accessed frequently by the farmers regarding with the farming by providing lots of information on farming.

Furthermore, the frequency of the information proved to be significantly connected with the farmer's level of knowledge. In other words, the more the farmers use LISA services the more knowledge the farmers get. According to the farmers, the most frequent feature being used is the Q\&A. Farmers felt facilitated by this service because they can ask directly to the counselors the problems, they are facing without waiting for the visit of the village counselor. In other words, this SMS feature is rated fast to respond to the farmer's problem.

\section{CONCLUSION}

This research shows that SMS that is used to deliver agricultural information has succeedded to empower farmers. The message a farmer receives has increased the farmer's knowledge and is used by the farmer to improve his farming. In addition, information the farmer receives through SMS is also used to intensify discussion between an intensive worker and farmers. This means that in order to strengthen the effects of message received by farmers through SMS, there needs to be a discussion between an intensive worker and farmers, and among farmers.

This research also signifies that there is a symptom of digital inequality among farmers. The different socio-economy status of farmers has caused a variety of gadget ownership, access, usage, and utilization of information received through SMS. This tendency must be noticed because digital inequality can probably expand the other socio-economy gaps.

\section{RECOMMENDATION}

This research has uncovered the digital divided and digital inequality phenomenon. These issues must be further researched by uncovering the most determined variables to uncover those injustices.

On improving the access of the farmers to the digital information sources, this research suggests for the stakeholders to open up more access for the farmers to the agricultural information by constructing ICT infrastructure in villages with cheaper tariff. In addition, a closer cooperation between the content provider and the extension workers must be tightened so the materials can be more relevant to farmers. Therefore, ICT becomes a complementary on the relationship between farmers and the extension workers

\section{REFERENCES}

Adegbidi, A. B., Mensah, R., Vidogbena, F., \& Agossou, D. (2012). Determinants of ICT use by rice farmers in Benin: from the perception of ICT characteristics to the adoption of the technology. Journal of Research in International Business and Management.

Aldosari, F., Al Shunaifi, M. S., Ullah, M. A., Muddassir, M., \& Noor, M. A. (2019). Farmers' perceptions regarding the use of Information and Communication Technology (ICT) in Khyber Pakhtunkhwa, Northern Pakistan. Journal of the Saudi Society of Agricultural Sciences, 18(2), 211217. https://doi.org/10.1016/j.jssas.2017.05.004

All Answers Ltd. (2018). Role of Information Communication Technologies (ICTs) for Rural Development.

Anastasios, M., Koutsouris, A., \& Konstadinos, M. (2010). Information and communication technologies as agricultural extension Tools: A survey among farmers in West Macedonia, Greece. Journal of Agricultural Education and Extension, 16(3), 249-263. https://doi.org/10.1080/1389224X.2010.489767 
Baumüller, H. (2013). Facilitating Agricultural Technology Adoption Among the Poor: The Role of Service Delivery Through Mobile Phones. In SSRN. https://doi.org/10.2139/ssrn.2237987

Daum, T. (2018). ICT Applications in Agriculture Abstract 1 Background 1 Areas of Application 2 Labor 2 Land 2 Agricultural Production 2 Financial Services 3 Insurance 3 Agricultural Extension Services 3 Machinery Rental Markets 4 Marketing 4 Consumption 4 Agricultural Re. In Encyclopedia of Food Security and Sustainability (Issue 2017). Elsevier. https://doi.org/10.1016/B978-0-12-812687-5.22591-4

FAO. (2010). The application of information and communication technologies in agricultural and rural development in Egypt. Research and Extensuin Branch.

Haight, M., Quan-Haase, A., \& Corbett, B. A. (2014). Revisiting the digital divide in Canada: The impact of demographic factors on access to the internet, level of online activity, and social networking site usage. Information Communication and Society. https://doi.org/10.1080/1369118X.2014.891633

Jain, L., Kumar, H., \& Singla, R. K. (2015). Assessing Mobile Technology Usage for Knowledge Dissemination among Farmers in Punjab. Information Technology for Development, 21(4), 668676. https://doi.org/10.1080/02681102.2013.874325

Lubis, D. (2010). Pemanfaatan teknologi informasi dan komunikasi mendukung pembangunan pertanian.

Meera, S. N., Jhamtani, A., \& Rao, D. U. M. (2004). Agricultural Research \&amp; Extension Network INFORMATION AND COMMUNICATION TECHNOLOGY IN AGRICULTURAL DEVELOPMENT: A COMPARATIVE ANALYSIS OF THREE PROJECTS FROM INDIA. In Agricultural Research \& Extension Network AgREN.

Ono, H., \& Zavodny, M. (2007). Digital inequality: A five country comparison using microdata. Social Science Research. https://doi.org/10.1016/j.ssresearch.2006.09.001

Park, S. (2017). Digital inequalities in rural Australia: A double jeopardy of remoteness and social exclusion. Journal of Rural Studies. https://doi.org/10.1016/j.jrurstud.2015.12.018

Pusat Penelitian dan Pengembangan Penyelenggaraan Pos dan Informatika. (2015). Pemanfaatkan dan Pemberdayaan Teknologi Informasi dan Komunikasi Jakarta.

Rendra, M., \& Wulandari. (2017). Using SMS Gateway's Model to Strengthen Agriculture's Stakeholders Relation with Farmers. 3rd International Conference on Transformation in Communications 2017 (IcoTiC 2017).

Robinson, L., Cotten, S. R., Ono, H., Quan-Haase, A., Mesch, G., Chen, W., Schulz, J., Hale, T. M., \& Stern, M. J. (2015). Digital inequalities and why they matter. Information Communication and Society. https://doi.org/10.1080/1369118X.2015.1012532

Sari, D., Praditya, D., \& Takariani, D. S. (2018). ICT Development Strategy for Rural Areas in West Java. International Conference on ICT for Rural Development (IC-ICTRuDev), 112-117. https://doi.org/doi: 10.1109/ICICTR.2018.8706873.

Senthilkumar, S., Chander, M., Serma Saravana Pandian, A., \& Sudeep Kumar, N. K. (2013). Factors associated with utilization of ICT enabled Village Information Centres by the dairy farmers in India: The case of Tamil Nadu. Computers and Electronics in Agriculture. https://doi.org/10.1016/j.compag.2013.07.018

Stiakakis, E., Kariotellis, P., \& Vlachopoulou, M. (2010). From the digital divide to digital inequality: A secondary research in the European Union. Lecture Notes of the Institute for Computer Sciences, Social-Informatics and Telecommunications Engineering. https://doi.org/10.1007/978-3-642-116315_4

The International Bank for Reconstruction and Development / The World Bank. (2011). ICT in Agriculture: Connecting Smallholders to Knowledge, Networks, and Institutions. In World Bank. https://doi.org/64605 